\title{
A Case of Ischemic Duodenitis
}

\section{Associated with Superior Mesenteric} Artery Syndrome Caused by an Abdominal Aortic Aneurysm

\author{
Yusuke Okuyama $^{\mathrm{a}}$ Takumi Kawakami $^{\mathrm{a}}$ Haruki Ito $^{\mathrm{b}}$ \\ Hirotomo Otsuka ${ }^{\mathrm{e}}$ Yasuyuki Enoki ${ }^{\mathrm{c}}$ Masahito Nishimura ${ }^{\mathrm{d}}$ \\ Norimasa Yoshida ${ }^{a}$ Sotaro Fujimoto ${ }^{a, f}$
}

Departments of a Gastroenterology, bUrology and ${ }^{\mathrm{C} C l i n i c a l ~ P a t h o l o g y, ~ K y o t o ~ F i r s t ~}$ Red Cross Hospital, and dDepartment of Cardiovascular Medicine, Toujinkai Hospital, Kyoto, eOtsuka Clinic, Kyoto, and fAkashi Municipal Hospital, Akashi, Japan

\section{Key Words}

Ischemic duodenitis · Superior mesenteric artery syndrome $\cdot$ Abdominal aneurysm

\begin{abstract}
A 74-year-old woman was admitted to our hospital with upper abdominal pain and bloody vomiting. An abdominal aneurysm compressed the third portion of the duodenum and the second portion of duodenum was distended with thickened walls as in superior mesenteric artery syndrome. Endoscopic examination showed an edematous mucosa with hemorrhagic erosions, shallow longitudinal ulcers, and star-shaped ulcers in the duodenum. We diagnosed this case as ischemic duodenitis associated with superior mesenteric artery syndrome caused by compression by an abdominal aortic aneurysm. The symptoms improved on treatment with bowel rest, total parenteral nutrition and administration of a proton pump inhibitor. We present here a rare case of ischemic duodenitis and summarize the previous medical literature on the disease.
\end{abstract}

\section{Introduction}

Ischemic change in the duodenum is very rare. It has been related with severe atheromatous disease of the abdominal splanchnic arteries. We present a case of ischemic duodenitis associated with superior mesenteric artery (SMA) syndrome caused by a large abdominal aortic aneurysm. 


\section{Case Report}

A 74-year-old woman was admitted to our hospital with upper abdominal pain, bloody vomiting and melena. She had a history of abdominal aortic aneurysm and end-stage renal disease caused by diabetes mellitus. She had been on dialysis for several years in another hospital. On physical examination, her consciousness was clear. Blood pressure was $180 / 70 \mathrm{~mm} \mathrm{Hg}$ and pulse rate 93 beats $/ \mathrm{min}$. She had a slight fever of $37.7^{\circ} \mathrm{C}$. Palpation of the upper abdominal quadrant was painful. Nausea and bilious vomiting persisted. Laboratory examination showed normocytic anemia, an elevated white cell blood count (WBC), elevated levels of C-reactive protein (CRP), AST, ALT and ALP, and hypoalbuminemia (table 1).

Contrast-enhanced abdominal computed tomography (CT) demonstrated an abdominal aneurysm with mural thrombus with a size of $30 \mathrm{~mm}$. It severely compressed and obstructed the third portion of the duodenum with the SMA (fig. 1a). The oral side of the duodenum was distended remarkably. Dynamic study of the abdominal CT demonstrated that there was no mural thrombus in the SMA (fig. 1b). Taking this into account, we diagnosed this condition as SMA syndrome. The amount of fluid aspirated from the nasogastric tube was reduced by changing to the left decubitus position, which is a typical treatment for SMA syndrome. Upper gastrointestinal X-ray study with Gastrografin through the nasogastric tube demonstrated a granular protruded lesion, a shallow niche and stenosis of the third portion of duodenum (data not shown). Gastroduodenoscopy demonstrated hemorrhagic erosions, shallow longituidal ulcers in the third portion (fig. $2 \mathrm{a}$ ) and star-shaped ulcers with edematous mucosa in the second portion of the duodenum (fig. 2b). Histopathological examination of the duodenal mucosal erosions showed bleeding and polymorphonuclear cell infiltration due to nonspecific inflammation (data not shown). In this case, the patient had taken neither antibiotics or nonsteroidal antiinflammatory drugs before the onset of the illness. Colonoscopy was performed and no abnormalities were found in the terminal ileum, colon, and rectum. Cultures of intestinal fluid and stool produced no growth of pathogenic organisms and no ova or parasites were observed on stool examination. Immunohistochemical examination revealed no findings of cytomegalovirus infection in the biopsy specimen of the duodenal mucosa. Finally, we diagnosed this case as ischemic duodenitis associated with SMA syndrome caused by compression by an abodominal aortic aneurysm. The symptoms improved on treatment with bowel rest, total parenteral nutrition and administration of a proton pump inhibitor. On the 59th hospital day, the endoscopic findings showed improvement of duodenal mucosal lesions.

\section{Discussion}

Ischemic duodenitis caused by splanchnic arterial insufficiency is very rare because of the rich collateral blood supply of the duodenum. This disease is only observed when at least two of three main splanchnic arteries are occluded or severely stenosed with severe atheromatous disease [1-7]. The duodenal blood supply arises mainly from the SMA via pancreaticoduodenal collaterals. In this case the jejunum might not have fallen into ischemic state on abdominal enhanced CT. Therefore, the abdominal aneurysm had not directly obstructed the blood supply of the main splanchnic arteries. The abdominal aneurysm had compressed the third portion of the duodenum, then it might have been involved in the transient increase of duodenal inner pressure through SMA syndrome.

Several cases of SMA syndrome caused by abdominal aortic aneurysms have been reported in the world [8-10]. The risk factors of SMA syndrome is severe wasting disease, prolonged bed rest, anorexia nervosa, malabsorption, and use of a body cast [11]. In this case, the patient was suffering from diabetes mellitus and chronic renal failure. In addition to such risk factors, direct compression of the third portion of the duodenum by the abdominal aneurysm might be related with the onset of ischemic duodenitis through the transient decrease of SMA blood supply. 
There were six previously published case reports of ischemic duodenitis, referring to MEDLINE (from 2000 to 2010) and Igaku Chuo Zasshi (from 2000 to 2010), as shown in table 2. In all cases, the patients were over 60 years old and were suffering from several atheromatous diseases [2-7]. As for treatment, conservative therapy was effective with 'transient' ischemic cases. However, in cases of SMA stenosis, angioplasty or stenting of the splanchnic arteries was needed.

This case seems to be the first case in whom a 'transient' ischemic duodenitis had been involved in SMA syndrome caused by an abdominal aortic aneurysm. We present here a rare case and summariz the previous medical literature on the disease.

\section{Disclosure Statement}

The authors have no conflict of interest.

Table 1. Laboratory data on admission

\begin{tabular}{llllll}
\hline WBC & $18,070 / \mu \mathrm{l}$ & Total protein & $6.4 \mathrm{~g} / \mathrm{dl}$ & Blood urea nitrogen & $126 \mathrm{mg} / \mathrm{dl}$ \\
$\mathrm{RBC}$ & $280 \times 10^{4} / \mu \mathrm{l}$ & Albumin & $2.2 \mathrm{~g} / \mathrm{dl}$ & Creatinine & $6.75 \mathrm{mg} / \mathrm{dl}$ \\
$\mathrm{Hb}$ & $8.6 \mathrm{~g} / \mathrm{dl}$ & AST & $131 \mathrm{IU} / \mathrm{l}$ & $\mathrm{HbAlc}$ & $5.5 \%$ \\
$\mathrm{Ht}$ & $26.4 \%$ & $\mathrm{ALT}$ & $71 \mathrm{IU} / \mathrm{l}$ & $\mathrm{CRP}$ & $16 \mathrm{mg} / \mathrm{dl}$ \\
$\mathrm{MCV}$ & $94.2 \mathrm{fl}$ & $\mathrm{LDH}$ & $289 \mathrm{IU} / \mathrm{l}$ & $\mathrm{HCV}$ antibody & positive \\
$\mathrm{MCH}$ & $30.7 \mathrm{pg}$ & ALP & $720 \mathrm{IU} / \mathrm{l}$ & HBs antigen & negative \\
$\mathrm{MCHC}$ & $32.5 \%$ & $\gamma$-GTP & $162 \mathrm{IU} / \mathrm{l}$ & Cytomegalovirus pp65 antigen & negative \\
Platelets & $15.3 \times 10^{4} / \mu \mathrm{l}$ & T-bilirubin & $1.1 \mathrm{mg} / \mathrm{dl}$ & Antinuclear antibody & negative \\
\hline
\end{tabular}

Table 2. Previous reports of ischemic duodenitis

\begin{tabular}{|c|c|c|c|c|c|}
\hline Age & Sex & Underlying disease & Treatment & Reference & Year \\
\hline 66 & M & myocardial infarction & conservative & Ukegawa et al. [2] & 2001 \\
\hline 61 & M & SMA stenosis & balloon dilatation & Sato et al. [3] & 2005 \\
\hline 63 & M & SMA stenosis & stenting & Seno et al. [4] & 2005 \\
\hline 69 & M & hypertension, diabetes, atrial fibrillation & conservative & Watanabe et al. [5] & 2006 \\
\hline 67 & M & Parkinson's disease & conservative & Hirahata et al. [6] & 2007 \\
\hline 80 & $\mathrm{~F}$ & $\begin{array}{l}\text { diabetes, hypertension, chronic renal failure, } \\
\text { lymphatic leukemia }\end{array}$ & conservative & Korswagen et al. [7] & 2007 \\
\hline 74 & $\mathrm{~F}$ & SMA syndrome, chronic renal failure, diabetes & conservative & Okuyama et al. & 2011 \\
\hline
\end{tabular}




\begin{tabular}{|c|c|c|c|}
\hline $\begin{array}{r}\text { Case Reports in } \\
\text { Gastroenterology }\end{array}$ & $\begin{array}{l}\text { Case Rep Gastroenterol 2011;5:278-282 } \\
\text { DOI: } 10.1159 / 000328442\end{array}$ & $\begin{array}{l}\text { Published online: } \\
\text { May 6, } 2011\end{array}$ & $\begin{array}{l}\text { @ } 2011 \text { S. Karger AG, Basel } \\
\text { ISSN 1662-0631 } \\
\text { www.karger.com/crg }\end{array}$ \\
\hline
\end{tabular}
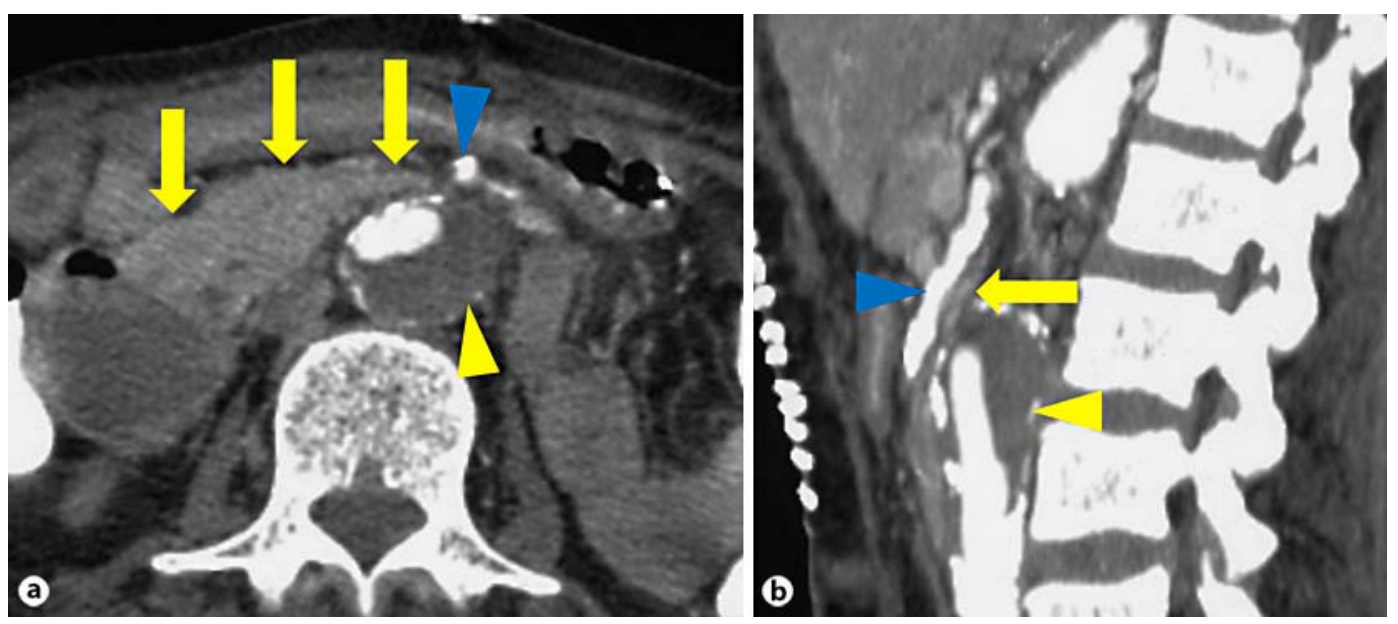

Fig. 1. a Contrast-enhanced abdominal CT (axial slice) showed that an abdominal aneurysm with mural thrombus compressed the third portion of the duodenum with SMA. Yellow arrows: the third portion of the duodenum with severely thickened wall. Yellow arrowhead: the abdominal aneurysm. Blue arrowhead: SMA. b Dynamic study of the abdominal CT (sagittal slice) showed that the third portion of the duodenum was pinched between the SMA and the abdominal aneurysm. There were no mural thrombus in the SMA. Yellow arrow: the stenotic site of the third portion of the duodenum. Yellow arrowhead: the abdominal aneurysm. Blue arrowhead: SMA.
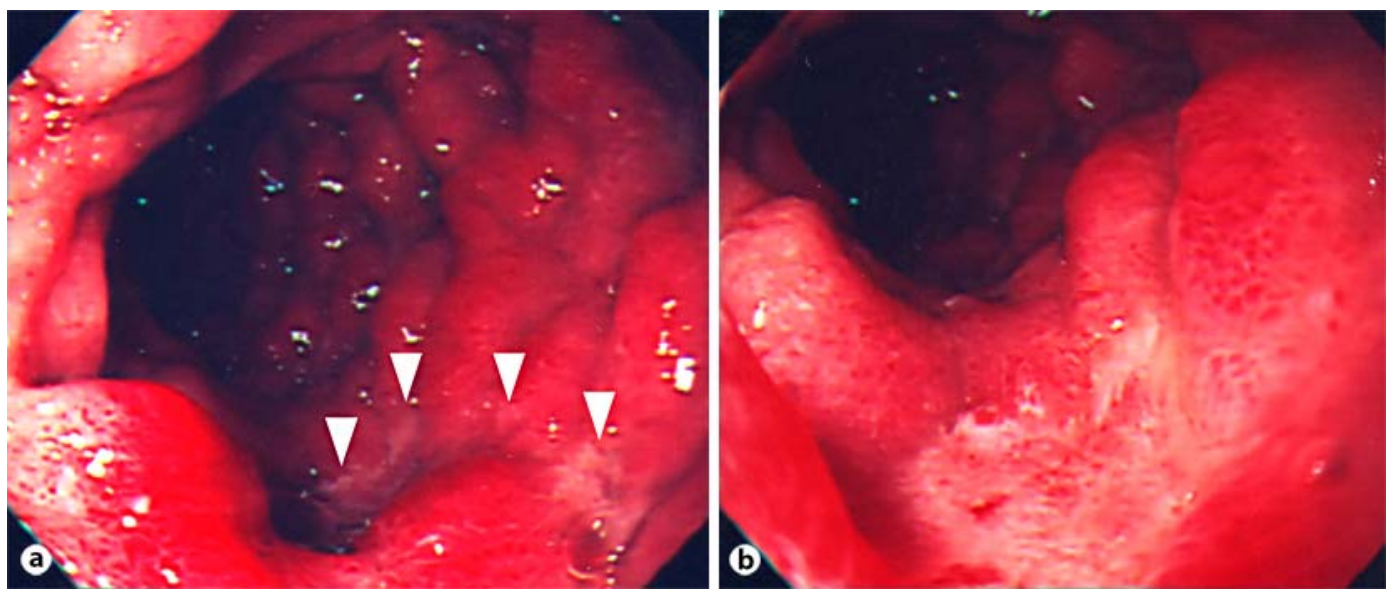

Fig. 2. Gastroduodenoscopy on admission showed an edematous reddish mucosa with hemorrhagic erosions, shallow longitudinal ulcers in the third portion (a, arrowheads), and star-shaped ulcers were observed in the second portion of the duodenum (b). 


\begin{tabular}{|c|c|c|c|}
\hline $\begin{array}{r}\text { Case Reports in } \\
\text { Gastroenterology }\end{array}$ & $\begin{array}{l}\text { Case Rep Gastroenterol 2011;5:278-282 } \\
\text { DOI: } 10.1159 / 000328442\end{array}$ & $\begin{array}{l}\text { Published online: } \\
\text { May 6, } 2011\end{array}$ & $\begin{array}{l}\text { @ } 2011 \text { S. Karger AG, Basel } \\
\text { ISSN 1662-0631 } \\
\text { www.karger.com/crg }\end{array}$ \\
\hline
\end{tabular}

\section{References}

$\longrightarrow$ Force T, MacDonald D, Eade OE: Ischemic gastritis and duodenitis. Dig Dis Sci 1980;25:307-310.

2 Ukegawa J, Kamisuna T, Takahashi S: A case of ischemic duodenitis (in Japanese with English abstract). Endosc Forum Dig Dis 2001;17:21-27.

3 Sato S, Matsunaga H, Tsuzuki Y: A case of chronic proximal superior mesenteric arterial ischemia showing gastroduodenitis treated by percutaneous recanalization (in Japanese with English abstract). Nippon Shokakibyo Gakkai Zasshi 2005;102:578-582.

4 Seno H, Mikami K, Komatsu S: Ischemic duodenitis. Endoscopy 2005;37:91.

5 Watanabe M, Imaizumi H, Yamagata H: A case of ischemic duodenitis (in Japanese with English abstract). Prog Dig Endosc 2006;68:118-119.

6 Hirahata K, Fujinuma S, Kakemura T: A case of duodenitis considered to be ischemic change (in Japanese with English abstract). Progr Dig Endosc 2007;70:94-95.

7 Korswagen L, Voerman HJ, Peterse JL: Ischemic duodenitis without involvement of the large abdominal arteries. Endoscopy 2007;39(suppl 1):E271.

8 Saraya T, Kurai D, Ariga M: Superior mesenteric artery syndrome caused by huge mycotic abdominal aortic aneurysm. Intern Med 2009;48:1065-1068.

-9 Komai H, Naito Y, Fujiwara K: Superior mesenteric artery syndrome as a result of enlarged abdominal aortic aneurysm. J Vasc Surg 1999;29:1162-1163.

10 Edwards KC, Katzen BT: Superior mesenteric artery syndrome due to large dissecting abdominal aortic aneurysm. Am J Gastroenterol 1984;79:72-74.

11 Hines JR, Gore RM, Ballantyne GH: Superior mesenteric artery syndrome. Diagnostic criteria and therapeutic approaches. Am J Surg 1984;148:630-632. 